\title{
ADDRESSING UDUMA'S AFRICANNESS OF A PHILOSOPHY QUESTION AND SHIFTING THE PARADIGM FROM METAPHILOSOPHY TO CONVERSATIONAL PHILOSOPHY
}

DOI: http://dx.doi.org/10.4314/ft.v4i1.3

\author{
Jonathan O. CHIMAKONAM PhD \\ Department of Philosophy, University of Calabar, Nigeria
}

\begin{abstract}
This conversation is inspired by Uduma O. Uduma's essay entitled "The Question of the 'African' in African Philosophy: In search of a Criterion for the Africanness of a Philosophy". In this essay, Uduma coined what he calls "the Africanness of a Philosophy Question which consists in the ultimate criterion for African philosophy. He was not the first to dwell on the Africanness issue in African philosophy but he was the first, to my knowledge, to christen it as such. Before Uduma framed the question into a proper metaphilosophical concern in African philosophy, old campaigners like Paulin Hountondji, Odera Oruka, Peter Bodunrin, Kwasi Wiredu, Sophie Oluwole, Innocent Onyewuenyi, etc., have all dwelt on it with some going more in-depth than others. I have also dwelt partly on this question before in an essay entitled "The Criteria Question in African Philosophy: Escape from the Horns of Jingoism and Afrocentrism". Incidentally, my treatment of the issue was not digestive enough as I did not mention the likes of Bodunrin, Wiredu, Oluwole and even Uduma himself - a terrible short-sightedness - one that I wish to correct in this discussion. My first aim in this work is to attempt to settle this metaphilosophical vicious circle once and for all. On the basis of this, I wish also to orchestrate a shift from the vicious circle of metaphilosophical engagements to a more fruitful conversational engagement in contemporary African philosophy. Our method shall consist in critical conversationalism. ${ }^{1}$
\end{abstract}

Keywords: Africanness question, African philosophy, criteria question, metaphilosophy, conversational philosophy

${ }^{1}$ Conversationalism and philosophical conversationalism should both be considered cognates to critical conversationalism. This is a method of philosophizing in which critical rigour combines with Mdialectical reasoning to decompose old thoughts and shade them of their structural Mencumbrances; to create and wherever necessary compose new thoughts and possibly obtain a Dosynthetic blend. My use of the concept of "blend" is adopted from Mark Turner's [The Origin of こIdeas], 2014. Oxford University Press: New York. Paperback. In blending, conversationalism highlights the possibility of blending two variables to identity and to uniqueness. Cf. J. $\mathrm{O}$. Chimakonam. "Some Emerging Methods in African Philosophy." Forthcoming 


\section{Introduction}

This encounter with some notable actors on the issue of the Africanness of a philosophy question is scheduled here not for the sake of argument but because it is necessary to the project of contemporary African philosophy. Like I stated in the abstract, I had elsewhere taken up this concern but not as the central concern of that work. Although I do not intend to change my line of argument in the essay referred to, I shall have to deepen and strengthen it in the light of the theses of the thinkers mentioned above. I shall employ the method of conversationalism in analyzing the thoughts of thinkers relevant to the Africanness of a philosophy concern. The goal shall be to demonstrate the inherent inadequacy of their thoughts. And on the basis of that project a better criterion for African philosophy.

On another hand, I shall make advocacy for African philosophers to channel more attention to phenomenological concerns. For as Bruce Janz enthused, the question of African philosophy needs to be re-asked, not from an essentialist/metaphilosophical but from a phenomenological point of view in order for African philosophy to properly attend to the conditions in which its questions arise (JANZ 2009, 7 \& 2). This advocacy it must be noted is for a shift and not for an outright abandonment of metaphilosophy.

We shall in this essay begin with the conversation on the Africanness of a philosophy and end with the advocacy for a paradigm shift. This conversation therefore is with the views of the actors already listed and in particular, with that of Uduma O. Uduma. I shall like to begin with Paulin Hountondji.

\section{HOUNTONDJI, Paulin. [African Philosophy: Myth and Reality, Rev. Second ed.], 1996. Indiana University Press: Bloomington Indianapolis. Paperback.}

In the first edition of his monumental work African philosophy: Myth and Reality (1983), Paulin Hountondji declared: "By 'African philosophy' I mean a set of texts, specifically the set of texts written by Africans and described as philosophical by their authors themselves (HOUNTONDJI 1996, 33)." This can be called the "geographic origin" criterion and which has persisted in some of Hountondji's earlier writings. Following scathing criticisms from different quarters especially from Yai, O. Babalola a man he describes as one of his harshest critics (HOUNTONDJI 1996,

xi) Hountondji amended his position in the preface to the second edition of his book (1996). The new position reads: "By 'African philosophy' I mean the set of philosophical texts produced (whether orally or in writing) by Africans (HOUNTONDJI 1996, xii)." Thus, the ultimate criterion and justification for African philosophy as far as Hountondji is concerned is that it be a written or oral production by an African which has the characteristics of universal philosophy. The 'African' $\checkmark$ from his usage merely refers to the geographical origin of the author (to give a work Mthe stain of African authenticity) whose production must be analytic, and reflect the ogpattern of critical individual discourse to qualify a work as philosophy (HOUNTONDJI 1996, 62-70). Evidently, Hountondji's criterion was primarily posited to answer the dicey question that members of his school (Universalist) faced, 
to wit: how can a work be philosophy and African at the same time? But even as he ties up the bag from one end, it bursts from another.

This geographic origin (criterion) presented by Hountondji stands on a quick sand. If any philosophical discourse produced by an African whether it has anything to do with Africa or not (HOUNTONDJI 1996, 65) qual ifies as African philosophy; would Hountondji wish this to be a universal standard by which different philosophical traditions are identified? If yes, then different philosophical traditions such as the Western, the Oriental, the African, etc., would simply be racial philosophies. Even this queer proposal is against the position of the Universalists. This proposal which is a direct implication of Hountondji's criterion would not only be abstruse but more seriously would eclipse the universality of thought. The talk of philosophical reason being the crest on which philosophy as a common human heritage rides, would become nonsensical. This is because; every philosophical tradition would become essentially culture-bound, strictly unique and substantially different from others for the implication of Hountondji's position to hold. The thesis that philosophical reason in its particular manifestations in philosophical places is continuously in motion striving for the universal would crumble. But we know, even if intuitively, that philosophical reason is at the centre of the philosophical endeavour which means that Hountondji could not have been more in error.

Hountondji may have laid out his arguments with good intentions but my position is that the geographic origin criterion false-started and is not ready-witted to support his probably other well-argued thoughts. Hountondji spent a great deal of time arguing that why ethnophilosophy must be replaced with a rigorous individual discourse that is in tune with universal appurtenances of philosophy is because it unwittingly commits Africans to the hands of the Europeans who taunt them as pre logical. However, his criterion that African philosophy can only be produced by Africans directly commits Hountondji to the same position he tries to flee from. I have elsewhere referred to this as Hountondji's dilemma. ${ }^{2}$ Thus we establish the inadequacy of Hountondji's geographic origin criterion.

\section{ORUKA, Odera. "The Fundamental Principles in the Question of African Philosophy". [Second Order],Vol 4. No 1. (Jan. 1975), pp. 44-65}

Odera Oruka the illustrious Kenyan philosopher did better than Hountondji by my own estimation in what constitutes the criteria for African philosophy. He started by distinguishing two senses of philosophy as a universal disciple. While one makes reference to topics discussed by all the philosophers in the world regardless of their background, the other refers to the body of knowledge whose truth can be proved by methods which are independent of any personal, national or racial values and $\Omega$ feelings (ORUKA 1975, 45). Thus for him philosophy must be a discipline which

I have technically called this the Hountondji's dilemma. Cf. Jonathan O. Chimakonam. "Dating and Periodization Questions in African Philosophy". [Atuolu Omalu: Some Unanswered Questions in Contemporary African Philosophy], p. xiii, 2015. University Press of America: Lanham. 
employs principles that are objectively granted, or else that are rationally (logically) warrantable. And these principles, he maintains, if true, are true regardless of the person or place from which they originate (ORUKA 1975, 46). Adopting the second sense, Oruka went ahead to argue that though, this being the universal idea of philosophy; it is consistent with the idea of African philosophy as with other traditions in philosophy. This is due to the fact that every tradition in philosophy is philosophy primarily, because it has the universal characteristics.

However, Oruka had to distinguish between African philosophy in a unique sense which he says is debased and mythical and African philosophy in a simple sense which is the authentic African philosophy (ORUKA 1975, 47). He therefore presented the criteria of authentic African philosophy as follows:

Now it is possible and necessary that the con cern for African philosophy is a demand for African philosophy not in the unique sense, but only in the simple sense. Here a piece of African philosophy would deserve to be described as 'African philosophy' simply in the sense that either (i) it is a work of an African thinker or philosopher (regardless of its subject-matter); or (ii) that it is a work dealing with a specific African issue, formulated by an indigenous African thinker, or by a thinker versed in African cultural and intellectual life. (ORUKA 1975, 50)

This may be called "the many-option criteria," since Oruka presented them as disjuncts in which any could suffice. Thus Oruka added one other criterion to the one provided by Hountondji to make his two although with more options. But had Oruka married them with a conjunction, it would have made his postulation a lot stronger than that of Hountondji rather; he carefully chose a disjunction probably not to discredit a fellow Universalist. So, by implication, either Hountondji's or his criterion would suffice in making a discourse African philosophy. What however places Oruka's criterion on a higher pedestal is the admission that any such discourse that treats African issue or even non-African issues whether produced by an African or a non-African would qualify as African philosophy.

Consider the sense of Oruka's definition of universal philosophy which gives him the leverage to agree that African philosophy is consistent with it. This definition consists of two clauses namely: (i) "the truth of philosophy can be proved by methods which are independent of any personal, national or racial values and feelings" (ii) that "philosophy is a discipline which employs principles that are objectively granted or else that are rationally (logically) warrantable (ORUKA 1975, 46)."

Then two paragraphs down the same page where he tries to show that this muniversalist thesis is consistent with African philosophy he states:

That philosophy is universal does not mean that all the philosophers must have similar interests and employ similar methods in philosophy. Neither does it mean that all the rationally warrantable or objectively granted principles or 
methods must be identical or that they must establish similar truth. (ORUKA 1975, 46)

What was Oruka thinking when he penned down the words in the second disjunct? He referred to it (possible logical nuances), we all do so, although unconsciously. In this situation, it is hardly the case that Oruka did not at least, have the feeling that he was referring to different logic traditions. He seems to be aware because in the universal definition he offered earlier the word "logically" was enclosed in a parenthesis between "rationally" and "warrantable". So he must have intentionally omitted it when he evoked the same definition later to justify African philosophy. Obviously, he must have been shy to imply that a logic system that can be described as African must exist to undergird and shape inquiries in African philosophy.

But he boldly acknowledged immediately that "Two separate philosophical methods, both being rational, can be opposed to one another, similarly two methods of philosophical inquiry, both using rationally granted or warrantable principles, can come to dissimilar truth (ORUKA 1975, 46)." Any logician understand s the logical implications of these statements.

On the whole, Oruka's criteria which describe African philosophy as that discourse produced by an African or a non-African versed in African intellectual life whether on African or non-African topic is still not adequate. The inadequacy becomes obvious when one engages Oruka in a conversation. To start with, Oruka's criteria are captured in a number of disjuncts: (a) That African philosophy is that discourse produced by an African (b) or that it is that discourse produced by a nonAfrican who is versed in the African cultural and intellectual life (c) or that African philosophy is any discourse on any choice African issue (d) or that African philosophy is any discourse on any choice non-African issue. Granted the above, here is the shocker: When a non-African versed in the African intellectual life produces any philosophical discourse whose theme falls on non-African issue, at least, one of Oruka's criteria says that such a discourse qualifies as African philosophy. But we know this to be ridiculous as for example, when Edwin W. Smith who was versed in African cultural and intellectual life produced a work say on theology, Oruka's criterion says such qualifies as African philosophy simply because the producer Edwin W. Smith, though a non-African; though, his subject was not on a specific African issue, was nonetheless versed in Africa's cultural and intellectual life. The question therefore is: what is the connection between his proficiency in African culture and his work on theology that should confer on the latter the status of African philosophy? In this therefore consists the weakness and inadequacy of Oruka's criteria for African philosophy as discussed above.

Evidently, what makes a discourse African philoso phy transcends geography Mand authorship of a thought. Until the actors in African philosophy project are able to ogput their house in order concerning the standard of their philosophical practice, we may not have a clear vision of the philosophy we profess a s African. 
OLUWOLE, B. Sophie. Ed. [Readings in African Philosophy], 1989. Masstech Publications: Lagos. Paperback. \& NWALA. T. Uzodinma. [Igbo Philosophy], 1985. Lantern books: Lagos. Paperback.

Some have argued that what makes a discourse African philos ophy is that it has a stamp of African authenticity. Put differently, any work that is called African philosophy must carry African identity. This identity is to be found in African culture or world view. As such a work of African philosophy is expected to project this world view irrespective of how it is structured. T. Uzodinma Nwala and Sophie Oluwole are the major exponents of this African authenticity criterion. As Nwala explains African philosophy refers to the collection of basic beliefs or world view about the universe and man which a society holds in the light of the existing social environment (NWALA 1985, 4-6). Nwala suggests that it is the world view of the African that gives any thought espoused as African philosophy its authenticity or identity. Oluwole was more poignant when she states:

This task appears at first sight simple and straightforward. A literary piece from Africa is naturally African by the very token that it originated from Africa. But even if this were so, there is still the need to identify, characterize and if possible, rationally justify such works as constituting a literary tradition with specific features which make the group a distinctive cultural phenomenon probably different from some other well known cultural types. $(1991,209)$

What Oluwole tries to highlight in the above is the important place of cultural identity of any discourse to be regarded as African philosophy which alone gives it the African authenticity. The problem with the African authenticity criterion is that it easily leads to ethnographic studies and descriptive works. Above all, it leaves a very broad and disorganized scope for African philosophy. Virtually any work in African sociology, anthropology, literature, religion, etc., would by dint of this criter ion establish themselves as works in African philosophy.

BODUNRIN, Peter. "The Question of African Philosophy," [African Philosophy: The Essential Readings, Tsenay Serequeberhan Ed.], Pp63-86, 1991. Paragon House: New York. Paperback.

Peter Bodunrin in a sense framed his criteria in form of questions. He believes the answers to the questions shall constitute the criteria for African philosophy. He was not completely satisfied with the out-of-the-blue prescription Hountondji had given. He felt it was too simplistic. There should be clearer reasons and deeper suggestions $\infty$ as to why a piece of literature qualifies as African philosophy. That it has to be an Moral or written production of an African as Hountondji states was not very o.jinformative and convincing. In Bodunrin's words therefore: 
Recent discussions and further reflections on the matter have convinced me that the different positions as to the nature of African philosophy held by various contemporary Africans reflect different understanding of the meaning of philosophy itself. I now think that our not wholly terminological dispute as to what is and what is not to count as African philosophy cannot be settled without answering some important questions. Some of these questions are: what exactly are African philosophers trying to do, namely, what challenges are they trying to meet? What is the proper answer to these challenges? In other words, what would constitute an appropriate answer to the problems African philosophers are trying to solve? What is the difference between a piece of philosophical discourse and discourse in some other discipline? What is it for a given idea or philosophy to be correctly definable as African philosophy? I shall attempt in this paper to answer these and related questions. (Bodunrin 1991, 65-66)

The problem is that Bodunrin never really answered these questions in ways that will bring out his views as to the criteria a discourse would have to meet before it qualifies as African philosophy. But in analyzing the position of the philosophic sagacity later on Bodunrin stated what some like Uduma $(2014,138)$ have taken to be a statement of his criterion thus: any group of philosophers engaged with some philosophical exercise are doing African philosophy only because the participan ts are Africans or are working in Africa and are interested in a philosophical problem (howbeit universal) from an African point of view (BODUNRIN 1991, 72).

From the foregoing and according to Uduma O. Uduma, Bodunrin in the above made a minor adjustment to Hountondji's criterion. He was able to split the geographic criterion into two components to wit; origin and location. While Hountondji's criterion was that of geographical origin in which an actor is required to be an African that of Bodunrin is geographical location in which an actor is merely required to be working within the African context. This was an improvement if you like on Hountondji's criterion thought to be too strict by some. By Bodunrin's criterion, a non-African may now be able to produce African philosophy. This was not so different from one of Oruka's criteria already discussed and just as Oruka's criterion; it has its own flaw. According to Uduma O. Uduma:

The major merit of Bodunrin's position lies in his recognition that non-African philosophers can do African philosophy but his insistence that such non-African philosophers must be working in Africa is illegitimate and not persuasive. (UDUMA 2014, 138)

I am inclined to agreeing with Uduma on that point. Additionally, I shall like to state that in no definite terms would the questions raised by Bodunrin lead to a clear articulation of the criteria for African philosophy little wonder his answers failed to

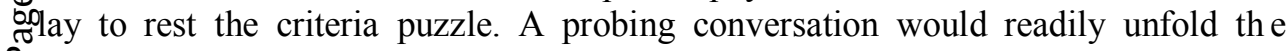
impotency of those questions. To begin with, we may have to sum up his questions in two simple ones: what is the problem that an African philosopher/philosophy aims to 
solve? And what is the correct answer to this question? So in the main, there is only one question namely; what is the correct answer to the question about the problem that an African philosopher/philosophy aims to solve? Essentially, I think this question is incorrectly framed by Bodunrin and as such is potentially misleading.

The idea of a correct answer or in his words a proper answer is misleading. It is difficult if not out rightly impossible to conceive one proper answer to that question. Would you say that African philosophy is one that aims to solve African problems? Or the one that aims to demonstrate the manifestation of philosophical reason from the African place whether or not it grapples with any specific African issue? Or the one that aims to enthrone the native African as its producer? Or the one that aims to locate any producer within Africa? These four answers representing many more that could be articulated are without doubt proper to Bodunrin's question depending on the inclination of the African philosopher. But are these answers sufficient to the question about what makes a given philosophical tradition different from another, (by far the truly proper question to be asked)? The answer is no! To locate the criteria of African philosophy, correct questions are not those framed at the micro level because the criteria question is not a micro question; it is rather a macro question. It is macro because it seeks to draw a line between various philosophical traditions. One cannot find this thin membrane within a designate philosophical place which is what most actors like Bodunrin have been doing but at a comparative philosophical space. It should therefore be noted that the value of philosophy as a questioning discipline lies not just on the importance of questions but more accurately, on the importance of "correct" questions. Incorrect questions are likely going to lead to incorrect answers at which behest the tools of philosophy would be vanquished.

\section{WIREDU, Kwasi. "On Defining African Philosophy", [African Philosophy: The} Essential Readings, Tsenay Serequeberhan Ed.], pp.87-110, 1991. Paragon House: New York. Paperback.

Kwasi Wredu in this essay was primarily concerned with understanding the nature of African philosophy through its definition. Definition he seems to suggest holds the key to the discovery of the criteria for what counts as African philosophy. He set off analyzing and exposing the weaknesses inherent in the articulations of his contemporaries notably Paulin Hountondji. His submission afterwards is that a proper definition of African philosophy must take into consideration process and issues such as (a) universal philosophical tools, because those are what make a discourse philosophy (b) African cultures and languages, because philosophy is culture relative (c) and exchanges among individual African philo sophers, because those are the proper modes of philosophical engagement (WIREDU 1991, 105). It is the stern warning of Wiredu that:

Any attempt on the part of a contemporary African philosopher to define African philosophy that does not take account of this process is out of touch 
with reality. But for him to take account of it is not just to take notice of it; it is for him to take a position with respect to it. For in this matter, he would not be merely trying to describe a phenomenon existing entirely independently of himself, but, rather, seeking to define the principles of his own practice. (WIREDU 1991, 105)

The above quote places emphasis on prescriptive individual discourse and their universal orientation as the veritable mode African philosophy must take. With this mode at the foreground, Wiredu identifies three criteria in ascending order each of which would be adequate for a discourse to be called African philosophy. The first 'option' as he calls it is collecting, interpreting, and retelling tho se of our traditional proverbs, maxims, conceptions, folktales, etc., that bear on the fundamental issues of human existence. But he says that this option would be chiefly reactionary and backward looking incapable of leading to modernity. The second option is to learn and disseminate and even possibly make original contributions to the philosophies of the Westerners. Again, he says that this would lead to the African ignoring his culture and committing himself to colonial mentality. This option which he de scribes as 'uncritical Westernism' for him would be unintelligent. The third option and which is the option he favors is captured in the following words:

For a body of thought to be legitimately associated with a given race, people, region or nation, it is sufficient that it should be, or should become, a living tradition therein. It is indifferent whether it is home brewed or borrowed wholly or partially from other peoples. Since we are, as has been repeatedly pointed out, still trying to develop a tradition of modern philosophy, our most important task is not to describe, but to construct and reconstruct. And the real issue regarding African philosophy is how best this may be done. (WIREDU 1991, 106-107)

I shall like to fault Wiredu's third criterion. The proper tradition of African philosophy necessarily has to be home brewed or at worst borrowed partly, on no justification would it be wholly borrowed and still remain African philosophy. In fact, the clause that allows African philosophical tradition to be wholly borrowed from any other tradition leads directly to what he criticized as colonial mentality or uncritical Westernism (WIREDU 1991, 106). However, of the three criteria given by Wiredu, it is in the third option that he placed greater credibility so I shall converse with him on that. This criterion literally states that for a discourse to qualify as African philosophy, it has to be constructed from ground up. We know from his $\checkmark$ exercise that is universally applicable; which takes cognizance of African culture Dosince for him philosophy is culture relative (WIREDU 1991, 106). What Wiredu fails ¿ to clarify however, is the model of this construction. He fails to observe that model is very important in constructing philosophical traditions. If not, Hegel's Lectures on 
the Philosophy of World History or Kant's Anthropology from a Pragmatic point of view or Levy Bruhl's Primitive Mentality where the trio did some constructions about Africa would qualify as African philosophy. It is not just construction or reconstruction that settles the matter, model is central. Wiredu probably noticed this lacuna in his criterion which is why he ended it by saying, "And the real issue regarding African philosophy is how best this may be done" (WIREDU 1991, 106 107). It is his inability to supply an answer to that question that vitiates his criteria for African philosophy.

\section{ONYEWUENYI, Innocent. "Is There an African Philosophy", [African Philosophy: The Essential Readings, Tsenay Serequeberhan Ed.], pp29-46, 1991. Paragon House: New York. Paperback.}

Innocent Onyewuenyi represents a group of African philosophers who hold fast to what they think is a model of thought common to all Africans south of the Sahara. They are convinced that the communitarian ontology is the bastion of African thought. Onyewuenyi is not alone in this view. William Abraham, John Mbiti, Olusegun Oladipo, T. Uzodinma Nwala, are some other actors who share this view which Kwasi Wiredu ridiculed as an exercise in "community thought" (WIREDU 1980, 14). Paulin Hountondji also lambasted them for been naïve in their inclination toward consensus or what he calls 'the myth of unanimity' (HOUNTOND JI 1996, 60-61).

Notwithstanding the harsh criticisms, most members of this school remain unrepentant. They variously defend their position and insist that any discourse that is not constructed on top of this communitarian ontology cannot be said to be A frican philosophy. For them therefore, the communitarian ontology is the insignia of African thought. It differentiates African philosophy from say, Western philosophy which rides on the crest of individualistic ontology. It is in connection with this that Onyewuenyi articulates the communitarian criterion as follows:

The discovery of African philosophy has influenced African scholars in writing about African personality or what the French speaking Africans call Negritude. Kwame Nkrumah, Julius Nyerere, Leopold Senghor, Aime Cesaire, Nnamdi Azikiwe, and Chinua Achebe have written prose and verse to celebrate this philosophy - a philosophy of unity and complete encounter of all things and beings, which by reason of the dynamic character of African ontology, has surfaced on the communal structure of our society based on the division of labour and rights; in which man attains growth and recognition by how well he fulfils a function for the over-all well-being of the community. (ONYEWUENYI 1991, 44-45)

Thus from the above, a discourse is African philosophy if and only if, it has the ¿communitarian model of thought as its background. The shortcoming of this criterion lies not in its logical vision but in its theoretic framing. The communitarian criterion 
is articulated to reflect some form of ontological prostitution where every variable is determined to serve the center and for the good of the center without the justification of critical reasoning. Hence, Wiredu says of this model that it gives the "impression that African philosophy is a monolithic body of argumentative communal beliefs, and nothing else" (WIREDU 1991, 95). Wiredu goes on to suggest that it is a "descriptive, theoretically unreconstructive model" (WIREDU 1991, 103). We shall in this work seek to transcend this level of explication (ontology) in our quest to fathom the true criteria for African philosophy.

UDUMA, O. Uduma. "The Question of the "African" in African Philosophy: In Search of a Criterion for the Africanness of a Philosophy," [Filosofia Theoretica: Journal of African Philosophy, Culture and Religions], Vol 3. No 1. Pp.127-146, 2014. Paperback.

Uduma has recently articulated the criterion question as the Africanness of a philosophy question (UDUMA 2014, 135). Besides my work of 2015 where I conceptualized the same problem as the criteria question (CHIMAKONAM 2015, 102), Uduma's attempt is next in line as the most recent. From the foregoing, the equivalence of the Africanness question and the criteria question can here be established. I have decided to revisit this metaphilosophical exercise because as I explained earlier my former attempt was not digestive. In his essay, Uduma criticized Hountondji, Bodunrin and Oluwole insisting that their criteria are not adequate. $\mathrm{He}$ went on to adopt Theophilus Okere's and C. B. Okolo's suggestions which he transformed into a criterion. For Okolo, what makes a philosophy African is its identification with the cultural, historical or existential experience of Africa/ns (OKOLO 1993, 33-4). On the other hand, Okere explains that African philosophy refers to a critical reflection either on a given universal phenomenon or a unique problem in Africa through the glasses of an African culture (OKERE 1976, 5). It is on the inspiration of these two that Uduma resolved that:

[w]hat makes a philosophy Western, African or Oriental is neither the geographical origin nor location of the author; rather it is the cultural and geographical content. It is, therefore, the cultural/geographical background/content of a philosophy that makes it African. For any philosophical work, system, theory or idea to be African, whether it is written by an African or non-African, it must have an African flavor. It must be a product of wonder from or on the African experience and the African world. (UDUMA 2014, 143)

Thus I shall like to call Uduma's criterion, "culture-dependent" criterion for the Africanness of a philosophy. There are two points Uduma makes in the above. First, he posits that philosophy is a child of wonder and second, he concludes based on the $\checkmark$ first that when this wonder resonates from an African cultural background which ๑D provides the material object for philosophizing, African philosophy is produced. In

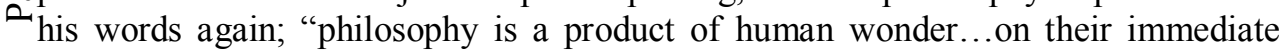
environment. This is what is meant when we say that philosophy is a child of 
circumstance" (UDUMA 2014, 142). To unfold the limitations in Uduma's criterion, we shall hold a brief conversation with him.

Even though, it is yet to be settled, when and where the history of systematic African philosophy began, recent researches tend to agree on the when even if not yet on the where. Both C. M. Okoro (2004, 77-102) and J. O. Chimakonam (2015, 12) date it back to the 1920's following the return of Africa's first eleven intellectuals who began their philosophizing with what is now called nationalist/ideological thinking. Chimakonam $(2015,4)$ goes on to posit that if this nationalist/ideological thinking targeted at colonialism and racialism was the first systematic attempt and correctly so, then, African philosophy or that philosophizing could not have begun in wonder. His conviction was that African philosophy, at least in its very first manifestation, began in frustration with the repressive colonial business. On this count, one of Uduma's Siamese criteria is slayed. It can be argued successfully, that latter developments in African philosophy may have had their source in wonder, but if Uduma's Siamese criteria were to be accepted, at least, one of its main implications would be that the nationalist/ideological discourses would be chopped off from the tree of African philosophy. This is not only unacceptable, but utterly ridiculous. The point made here is the gaping hole that exists in Uduma's culture-dependent criterion. It simply is not adequate.

Again, if cultural background is the Alchemist's stone that transform s any discourse into philosophy and draws a line between one philosophy tradition and another, Uduma was unable to identify those cultural elements that perform this magic. These cultural elements, if they exist, must be in the form of institutions, ceremonies, rituals, belief systems, and perhaps incantations; would Uduma grant for instance, that a discourse that would qualify as African philosophy must be done through incantations? Yet, this is the far-reaching implication of Uduma's criterion of cultural basis.

As interesting as his criterion sounds, we must note that in philosophy, things are not usually what they seem. It is by the analy-synthetic power of our method of conversationalism that cumbrous theses like Uduma's can be compelled to bear witness against itself. That cultural coloration of discourse is what characterizes different philosophical traditions sounds too simplistic for comfort. It is not just enough to make this type of big statement which do not have any concrete signification and simply go to sleep believing that the job has been done. Uduma should have been able to tell us exactly which cultural elements colors a discourse into Western, Oriental, and African philosophies, and how? Anyways, his failure to decide this and the weaknesses of other criteria articulated by others before him, form the justification for the criteria we shall offer in this work. 
CHIMAKONAM, O. Jonathan. "The Criteria Question in African Philosophy: Escape from the Horns of Jingoism and Afrocentrism", [Atuolu Omalu: Some Unanswered Questions in Contemporary African Philosophy, Jonathan O. Chimakonam Ed.], Pp101-123, 2015. University Press of America: Lanham. Paperback.

In this essay, we rejected as unnecessary and irrelevant the Hountondji's criterion that a discourse has to be produced by an African before it would qualify as African philosophy, but we retained Oruka's clause that any discourse can qualify as African philosophy whether it is by an African or non-African; whether it is on African or on non-African issue and on it erected an important and essential "logic criterion". We can therefore state the "logic criterion" thus:

(i) Any discourse that treats African or non-African issues whether produced by an African or non-African but is capable of universal application can qualify as African philosophy insofar as it is produced with the background logic of African ontology or the instrument of logic tradition in Africa which is dialectical in structure.

In suggesting a logic tradition for Africa, I probably have in the words of the dogged Nigerian philosopher Udo Etuk stirred the hornet's nest (ETUK 2002, 99). Some of the Universalists would regard this position as unapt and the idea of universal instrument of logic to be inconsistent with African logic or less horrifying, logic tradition in Africa. But my evocation of "African logic" is no different from similarly accepted evocations such as "Indian logic", "Chinese logic", "Arabic logic" to name a few which as far back as 1967 Paul Edwards proudly allocated esteem places to in the history of logic as treated in his [Encyclopedia of Philosophy Volume iv] (EDWARDS 1967, 520-528). My idea of logic tradition in Africa or simply African logic is perfectly consistent with the idea of universal logic any less than the ideas of universal philosophy and philosophy tradition in Africa. It is intellectual cowardice or colonialist stereotype that makes one assume that any time the predicate "African" is evoked in philosophy, a red flag is at once raised to signal the intrusion of ethocentricism. The preponderance of this sort of thinking has become sickening in our time. It is therefore, arguable that some architects of African philosophy project-Universalists included (whilst not denying them their credits) in the time of the debate and soon after, are in the habit of overlooking the definitional or foundational role of logic in any discourse called philosophy. So, it is apt to expect them reject the idea of an African logic at one hand and at another demonstrate it in their argumentation. This is however, not unconnected with the terrifying predicate $\mathbf{L}$ “African" placed in front of "logic". Indeed, Kwasi Wiredu in criticizing Victor $\checkmark$ Ocaya's work on [Logic within the Acholi Language] even suggested that this should onever be considered a reasonable project. He describes the idea of African logic as

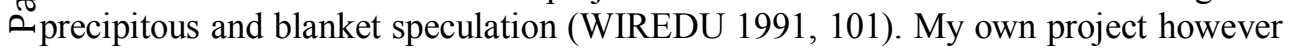
which has been called Ezumezu system is not exactly as those of Ocaya, Etuk, 
Ijiomah, etc., who attempt to describe what they feel is the structure of logic in their various cultures; Ezumezu does not describe how Africans reason that is different from how the rest of humanity reason; it takes inspiration from the dialectical model of thought common to all humanity Africa inclusive (specifically undergirding the well known communitarian ontology of the African tradition) to devise an alternative system of logic that could drive philosophizing in Africa. To drive philosophizing in African philosophy, one that would be absolved from the blame of transliteration of Western philosophy, an alternative model of thought is imperative. The concept of the "alternate" has no direct implication to "difference in substance" which is the erroneous basis of the assumptions associated with the concept of "African logic".

From the foregoing, the Ezumezu system is therefore called African logic because it is developed within the African philosophical tradition and with generous African ontological paraphernalia, to shape and undergird philosophical inquiries in Africa not as polemics suppose, it points to a unique African way of thinking. Again, this latter attribute of driving philosophical inquiries in Africa does not in any way vitiate its universal applicability. The fear then, that the evocation of "African" reawakens the idea of ethnophilosophy or any sort of unique, pure, culture-bound excavations is therefore unfounded. Thus devising a system of alternative logic model to direct the development of African philosophy is not merely ceremonial but acutely imperative. Godfrey Ozumba in this connection admonishes that "understanding the underlying African logic is sine qua non to understanding the latent philosophic wisdom which is embedded in African philosophic systems" (OZUMBA 2015, 184). This is what is required all along to jolt African philosophy out of the vicious circle of metaphilosophical dialogues and onto a path of architectonic growth and progress. Hence, the future direction of African philosophy can suc cessfully be charted only on the wheels of an alternative thought model. In the absence of this alternative thought model, African philosophy can hardly wash itself clean from the blame of transliteration. Already, some Western philosophers like Heinz Kimm erle and Jurgen Hengelbrock according to Ozumba accuse the architects of African philosophy of transliteration of Western thought (OZUMBA 2015, 181-184). Ozumba may have doggedly answered the charge of transliteration wherein he described his Western opponents as narrow-minded $(2015,174)$, the fact however remains, as Ozumba agrees and appears to suggest $(2015,184)$, that an alternative system of logic is necessary to drive inquiries in African philosophy project. C. S. Momoh observed long ago that this was the last piece of the African philosophy jigsaw and challenged African logicians to pick up the gauntlet of developing a system of logic that would drive African philosophy (MOMOH 2002,187). Ezumezu represents the accomplishment of this requirement.

Conclusion: Shifting the Paradigm from Metaphilosophy to Conversational ợhilosophy

A prospective critic may ask: what is wrong with metaphilosophy? The answer is nothing! It has been and remains a veritable philosophical paradigm. Our echo here is 
not to scrap it from the workshop of African philosophy but to sway more attention to other phenomenological paradigms. It should not be difficult for anyone to acknowledge that one thing which the post debate disillusionment leaves on the table is the urgent need for architectonic development of African philosophy. The resources required for this great (re)construction can hardly be supplied by metaphilosophy hence, our agitation for a paradigm shift.

To begin with, there are a few points it is apt for me to highlight here: (1) it should never be assumed that conversational philosophy is the only possible future oriented paradigm for African philosophy. It is just but one of many other possibilities (2) that conversational philosophy comes fitted with a method of thoug ht called connversationalism wherein key concepts such as nwa-nju, nwa-nsa, protestation, contestation, relational equilibrium, dialogical equilibrium, blend and blending to name a few play crucial roles in the composition and decomposition of thought (3) that philosophical conversation here has a stipulative meaning different from the lexical meaning in which a conversation could refer to an informal dialogue between two interlocutors (4) that philosophical conversation when employed in the discussion of phenomenological issues force a thought into a rack of reasoning and compel it to bear witness against itself in the form of new thoughts (5) that it is this ability to decompose and compose thoughts; synthesize and blend thoughts that presents conversational philosophy as a viable paradigm contemporary African philosophy should move to.

From the foregoing, to converse or hold a conversation literally means to have an informal exchange of ideas or information (SMITH 2004, 285). Here, we employ the term in a slightly more technical sense. Philosophical conversation for us is not a mere informal exchange of ideas or a simple informal dialogue between two interlocutors; it is rather a strictly formal intellectual exercise upheld by philosophical reasoning in which critical and rigorous questioning (in a dialectical process) creatively unveils new concepts from old ones making use of the tools of decomposition and blending. By conversational philosophy we mean that sort of philosophical engagement between individual thinkers with one another; on phenomenological issues of concern; or on one another's thoughts where thoughts are unfolded from the bowels of concepts or from concept of concepts. Conversational philosophy thus is more than a dialogue; it is an encounte $r$ between proponents and opponents or a proponent and an opponent engaged in contestations and protestations of ideas and thoughts. A conversational school therefore would be any circle of philosophical like minds who adopt this approach in their practice of philosophy. For me, this should now define not only the new era of African philosophy but the practice of philosophy generally in our age. This is because, more $\checkmark$ than ever before, the world of philosophy requires conversations both in place and in $\nabla_{\text {space. }}$

On the contrary, metaphilosophy is a philosophy-questioning-philosophy $\sim$ activity. In the African philosophy project, it has raised questions such as does African philosophy exist? This question alone took actors more than three decades to 
decide in that historic debate in African philosophy. The great debate was an era saturated with perverse dialogue centered on the justification of African philosophy by African philosophy. More than two decades have since passed since the debate was said to have ended; yet, the perverse orientation of the metaphilosophical kind persists to sustain a lingering vicious circle. If it is not about the identity of African philosophy or its practitioner; then, it is about its geography or its periodization, or its history, or as we delved into in this paper, its criterion. Actors continue to whirl within this vicious circle hoping for a break that increasingly appears difficult to obtain. Conversational philosophy therefore represents a midwifery machine that can help African philosophers deliver of their long overdue ideas and thoughts on phenomenological concerns.

Evidently, why we thought it appropriate to delve into the metaphilosophical concern of the criterion or the Africanness question is because, it is pertinent to settl e the crisis on what constitutes African philosophy and what does not. We cannot possibly move forward without this having being resolved. It is on the basis of a generally accepted criterion or criteria for African philosophy that actors can erect a viable episteme of African philosophy. Our attempt in this essay to resolve the lingering crisis about a criterion or criteria for the Africanness of a philosophy, it is hoped, would attract that general acceptance. We therefore, feel compelled on the basis of that, to make an advocacy for a shift of concentration from metaphilosophy to phenomenological concerns through the eyeballs of what we call conversational thinking. I have laid out the map of conversational philosophy and of conversationalism in other essays ${ }^{3}$ and as such would not be dwelling on them here. Besides this advocacy for a shift from the paradigm of metaphilosophical concerns to that of conversational thinking, we earlier engaged in a metaphilosophical concern as already stated, wherein we attempted to resolve the crisis of criteria that continues to stall the progress of African philosophy in the contemporary time. Engaging some vocal actors (by no means all) in critical conversations, we were able to identify loopholes in their various criteria which account for their inadequacy and hence, posit the "logic criterion" which we hope would suffice. The expectation is that the architects of African philosophy would begin not only to weigh in their productions but to also turn away much of their attentions from metaphilosophy.

${ }^{3}$ Cf. Jonathan O. Chimakonam. "Dating and Periodization Questions in African Philosophy". Atuolu Omalu: Some Unanswered Questions in Contemporary African Philosophy. Lanham: University Press of America, 2015; "History of African Philosophy". Internet Encyclopedia of Philosophy, Nov. 22, 2014. James Fieser and Bradley Dowden Ed. Retrieved, March 1, 2015. Par. 1; "Conversational Philosophy as a New School of Thought in African Philosophy: A Conversation with Bruce Janz on the Concept of 'Philosophical Space' [Confluence: Journal of World Philosophies, forthcoming]; "Transforming the African Philosophical Place through Conversations: An Inquiry into the Global Expansion of Thought (Get)", forthcoming. 


\section{Relevant Literature}

1. BODUNRIN, Peter. "The Question of African Philosophy," [African Philosophy: The Essential Readings, Tsenay Serequeberhan Ed.], Pp63-86, 1991. Paragon House: New York. Paperback.

2. CHIMAKONAM, O. Jonathan. "The Criteria Question in African Philosophy: Escape from the Horns of Jingoism and Afrocentrism", [Atuolu Omalu: Some Unanswered Questions in Contemporary African Philosophy, Jonathan O. Chimakonam Ed.], Pp101-123, 2015. University Press of America: Lanham. Paperback.

3. . . Dating and Periodization Questions in African Philosophy", [Atuolu Omalu: Some Unanswered Questions in Contemporary African Philosophy, Jonathan O. Chimakonam Ed.], pxiii, 2015. University Press of America: Lanham. Paperback.

4. ETUK, Udo. "The Possibility of African Logic", [The Third Way in African Philosophy, Olusegun Oladipo Ed.], 2002. Hope Publications: Ibadan. Paperback.

5. HOUNTONDJI, Paulin. [African Philosophy: Myth and Reality. Rev. Second edn.], 1996. Indiana University Press: Bloomington Indianapolis. Paperback.

6. EDWARDS, Paul Ed. [Encyclopedia of Philosophy, Volume iv], 1967. Macmillan Publishing co: New York. Paperback.

7. JANZ, Bruce. [Philosophy in an African Place], 2009. Lexington Books: Lanham. Paperback.

8. MOMOH, S. Campbell. "The Logic Question in African Philosophy", [The Substance of African Philosophy, C. S. Momoh Ed. $2^{\text {nd }}$ Edn.], 2000. APP Publications: Auchi. Paperback.

9. NWALA. T. Uzodinma. [Igbo Philosophy], 1985. Lantern books: Lagos. Paperback.

10. OKERE, Theophilus. "The Relation Between Culture and Philosophy", [Uche], Vol 2. 1976. pp4-11. Paperback.

11. OKOLO, C. B. [What is African Philosophy? A Short Introduction], 1987. Cecta: Enugu. Paperback. 
Paperback.

12. OKORO, C. Michael. [African Philosophy: Question and Debate, A Historical Study], 2004. Paqon Press: Enugu. Paperback.

13. OLUWOLE, B. Sophie. Ed. [Readings in African Philosophy], 1989. Masstech Publications: Lagos. Paperback.

14. ONYEWUENYI, Innocent. "Is There an African Philosophy", [African Philosophy: The Essential Readings, Tsenay Serequeberhan Ed.], pp29-46, 1991. Paragon House: New York. Paperback.

15. ORUKA, Odera. "The Fundamental Principles in the Question of African Philosophy". [Second Order],Vol 4. No 1. (Jan. 1975), pp44-65

16. OZUMBA, Godfrey. "The Transliteration Question in African Philosophy", [Atuolu Omalu: Some Unanswered Questions in Contemporary African Philosophy, Jonathan O. Chimakonam Ed.], Pp171-185, 2015. University Press of America: Lanham. Paperback.

17. SMITH, Stephenson Ed. [The New International Webster's Comprehensive Dictionary of the English Language: Encyclopedic Edition], 2004. Trident Press: Florida. Paperback.

18. TURNER, Mark. [The Origin of Ideas], 2014. Oxford University Press: New York. Paperback.

19. UDUMA, O. Uduma. "The Question of the "African" in African Philosophy: In Search of a Criterion for the Africanness of a Philosophy," [Filosofia Theoretica: Journal of African Philosophy, Culture and Religions], Vol 3. No 1. Pp127-146, 2014. Paperback.

20. WIREDU, Kwasi. [Philosophy and an African Culture], 1980. Cambridge University Press: Cambridge. Paperback.

21. __. "On Defining African Philosophy", [African Philosophy: The Essential Readings, Tsenay Serequeberhan Ed.], pp87-110, 1991. Paragon House: New York. Paperback. 